\title{
ANALISIS AKUNTANSI PENDAPATAN PERPAJAKAN DALAM RANGKA PENERAPAN AKUNTANSI BERBASIS AKRUAL Studi Kasus KPP Pratama Baubau
}

RUDI ABDULLAH

Fakultas Ekonomi Universitas Muhammadiyah Buton, Sulawesi Tenggara

Accounting gets accrual basis will result more information akuntabel, andal, and transparent as compared to accounting gets cash basis. Accounting gets accrual basic can provide the better measurement, admitting that timely, and liabilities cast in the future. Information gets accrual basis can provide information about economic resource purpose that actually. This research intent to know accounting implement gets accrual basis accord PP 71 years 2010 on taxations propertied accounting. This observational type is observational kualitatif. Sample that is utilized is taxation propertied data on Taxeses Ministering Office Pratama Baubau year 2014. To show observational result that KPP Pratama Baubau has performed taxation income accounting with accrual basis bases prevailing order, which is PP 71 years 2010 and ruling supporting another. Taxation income is admitted while its appearance commanding rights on propertied taxation. Taxations propertied registry be performed according to Accounting Default journals Institutions. Taxations Propertied reporting KPP Pratama Baubau is presented in Budget Realization Reporting and Operational Reporting. This research result is expected Commanding that make ready qualified Man Resource optimal ala and ready deep implemented accounting gets accrual basis so will result qualified Government Financial Statement and gets dipertanggung jawabkan.

Keywords: Taxation, Accounting income gets accrual basis 


\section{LATAR BELAKANG}

Laporan keuangan pemerintah disusun untuk menyediakan informasi yang relevan tentang posisi keuangan dan seluruh transaksi yang dilakukan oleh suatu entitas pelaporan selama satu periode pelaporan. Laporan keuangan digunakan untuk mengetahui nilai sumber daya ekonomi yang dimanfaatkan untuk melaksanakan kegiatan operasional pemerintahan, menilai kondisi keuangan, mengevaluasi efektivitas dan efisiensi suatu entitas pelaporan, dan membantu menentukan ketaatannya terhadap peraturan perundangundangan.

Tujuan umum penyajian informasi yang disajikan dalam laporan keuangan adalah untuk memenuhi kebutuhan informasi dari semua kelompok pengguna. Laporan keuangan pemerintah berperan sebagai wujud akuntabilitas pengelolaan keuangan negara, karena itu komponen laporan yang disajikan setidak tidaknya mencakup jenis laporan dan elemen informasi yang diharuskan oleh ketentuan peraturan perundang-undangan. Selain itu, karena pajak merupakan sumber utama pendapatan pemerintah, maka ketentuan laporan keuangan yang memenuhi kebutuhan informasi para pembayar pajak perlu mendapat perhatian. Kebutuhan informasi mengenai kegiatan operasional pemerintahan serta posisi kekayaan dan kewajiban dapat dipenuhi dengan lebih baik dan memadai jika didasarkan pada basis akrual, yaitu berdasarkan pengakuan munculnya hak dan kewajiban, bukan berdasarkan pada arus kas semata. Namun, apabila terdapat ketentuan peraturan perundang undangan yang mengharuskan penyajian suatu laporan keuangan dengan basis kas, maka laoran keuangan dimaksud wajib disajikan demikian.

Akuntansi berbasis akrual akan menghasilkan informasi yang lebih akuntabel, andal, dan transparan dibandingkan dengan akuntansi berbasis kas. Akuntansi berbasis akrual dapat menyediakan pengukuran yang lebih baik, pengakuan yang tepat waktu, dan pengungkapan kewajiban di masa mendatang. Informasi berbasis akrual dapat menyediakan informasi mengenai penggunaan sumber daya ekonomi yang sebenarnya.

Pendapatan dari sektor perpajakan merupakan komponen penyumbang pendapatan yang memiliki porsi terbesar dalam Anggaran Pendapatan dan Belanja Negara (APBN) Republik Indonesia. Berdasarkan alasan inilah implementasi tentang kebijakan, sistem, dan prosedur akuntansi pendapatan perpajakan merupakan hal yang sangat penting. Pendapatan perpajakan di Indonesia meliputi Pendapatan Pajak Penghasilan, Pajak Pertambahan Nilai, Pajak Bumi Bangunan, Bea Perolehan Hak atas Tanah dan Bangunan, dan Bea Meterai.

Pemerintah memiliki andil besar terhadap kebijakan, sistem, serta prosedur akuntansi yang dipakai dalam mengakui pendapatan perpajakan dalam kaitannya dalam menciptakan good governance. Salah satu upaya yang dilakukan oleh pemerintah Indonesia di bidang pengakuan dan pelaporan pendapatan perpajakan dalamrangka mencapai good governance adalah menerapkan akuntansi berbasis akrual dari yang semula menggunakan akuntansi berbasis kas menuju akrual terhadap akuntansi pendapatan perpajakan.

Selama ini pemerintah masih menggunakan Standar Akuntansi Pemerintahan (SAP) berbasis Kas Menuju Akrual yang berlandaskan pada Peraturan Pemerintah Nomor 24 Tahun 2005. Peraturan pemerintah ini mengatur bahwa pendapatan perpajakan diakui ketika kas masuk ke rekening negara. Penerapan basis kas ini memudahkan pencatatan dan pelaporan pendapatan pajak karena hanya berdasarkan pada pendapatan pajak tahun fiskal tertentu tanpa memperhatikan kapan sebenarnya pendapatan tersebut dihasilkan. Namun, hal ini menimbulkan kelemahan karena pendapatan yang dilaporkan menjadi kurang merepresentasikan keadaan sebenarnya sehingga pelaporannya menjadi kurang andal dan akuntabel.

Demi menerapkan Standar Akuntansi Pemerintahan berbasis akrual, pemerintah mengganti Peraturan Pemerintah Nomor 24 Tahun 2005 dengan Peraturan Pemerintah Nomor 71 Tahun 2010. Ruang lingkup Peraturan Pemerintah Nomor 71 Tahun 2010 meliputi SAP Berbasis Akrual dan SAP Berbasis Kas Menuju Akrual. SAP Berbasis Kas Menuju Akrual boleh diterapkan bagi entitas yang belum siap menerapkan SAP berbasis akrual dengan batas waktu empat tahun sejak tanggal ditetapkan.

Masalah dalam penelitian berdasarkan latar 
belakang yang telah diuraikan sebelumnya adalah Bagaimana penerapan akuntansi berbasis akrual sesuai PP 71 tahun 2010 pada akuntansi pendapatan perpajakan pada KPP Pratama Baubau?

Tujuan penelitian berdasarkan rumusan masalah yang diuraikan diatas adalah untuk mengetahui penerapan akuntansi berbasis akrual sesuai PP 71 tahun 2010 pada akuntansi pendapatan perpajakan pada KPP Pratama Baubau.

\section{METODE ANALISIS DATA}

Dalam suatu penelitian sangat diperlukan suatu analisis data yangberguna untuk memberikan jawaban terhadap permasalahan yang diteliti. Menurut Sugiyono (2010:89) analisis data adalah proses mencari dan menyusunsecara sistematis data yang diperoleh dari hasil wawancara, catatan lapangan,dan dokumentasi, dengan cara mengorganisasikan data ke dalam kategori menjabarkan ke dalam unit-unit, melakukan sintesa, menyusun ke dalam pola,memilih mana yang penting dan yang akan dipelajari, dan membuat kesimpulansehingga mudah dipahami oleh diri sendiri maupun orang lain.

Data-data yang dibutuhkan dalam penelitian ini berasal dari hasilwawancara, catatan lapangan, dan foto-foto sebagai data pendukung. Setelahdata-data ini diperoleh peneliti, maka akan dilakukan analisis data menggunakanpendekatan interpretif, di mana peneliti menginterpretasikan arti data-data yangtelah terkumpul dengan memberikan perhatian dan merekam sebanyak mungkinaspek situasi yang diteliti pada saat itu. Adapun tahapan-tahapan analisis data dalam penelitian ini sesuai dengan analisis data kualitatif model Miles dan Huberman (1992) dalam Sugiyono (2010:91), yaitu sebagai berikut:

1. Pengumpulan data, yaitu peneliti mencatat semua data secara objektif dan apa adanya sesuai dengan hasil observasi dan wawancara di lapangan.

2. Reduksi data, yaitu memilih hal-hal pokok yang sesuai dengan fokus penelitian. Reduksi data merupakan suatu bentuk analisis yang menggolongkan, mengarahkan, membuang yang tidak perlu dan mengorganisasikan datadata yang telah direduksi memberikan gam- baran yang lebih tajam tentang hasil pengamatan dan mempermudah peneliti untuk mencarinya sewaktu-waktu diperlukan.

3. Penyajian data, yaitu sekumpulan informasi yang tersusun yangmemungkinkan adanya penarikan kesimpulan dan pengambilan tindakan.Penyajian data merupakan analisis dalam bentuk matrik, network, atau grafis sehingga data dapat dikuasai.

4. Pengambilan keputusan atau verifikasi, berarti bahwa setelah data disajikan, maka dilakukan penarikan kesimpulan atau verifikasi. Untuk itu diusahakan mancari pola, model, tema, hubungan, persamaan dan sebagainya. Jadi, dari data tersebut berusaha diambil kesimpulan. Verifikasi dapat dilakukan dengan keputusan didasarkan pada reduksi data, dan penyajian data yangmerupakan jawaban atas masalah yang diangkat dalam penelitian.

Keempat komponen tersebut saling interaktif yaitu saling mempengaruhi dan terkait. Pertamatama dilakukan penelitian di lapangan dengan mengadakanwawancara atau observasi yang disebut tahap pengumpulan data. Karena datadata, pengumpulan penyajian data, reduksi data, kesimpulan-kesimpulan ataupenafsiran data yang dikumpulkan banyak maka diadakan reduksi data. Setelahdireduksi maka kemudian diadakan sajian data, selain itu pengumpulan data jugadigunakan untuk penyajian data. Apabila ketiga hal tersebut selesai dilakukan,maka diambil suatu keputusan atau verifikasi.

\section{PEMBAHASAN}

\section{Pengakuan Pendapatan Perpajakan Berbasis Akrual Penuh di KPP Pratama Baubau}

Berdasarkan hasil wawancara dengan Kepala Sub Bagian Umum dan Kepatuhan Internal diketahui bahwa untuk tahun 2015 KPP Pratama Baubau telah menerapkan basis akrual secara penuh sesuai dengan amanah pemerintah melalui PP Nomor 71 Tahun 2010. Dalam PP 71 tahun 2010 salah satu ciri utama dari penerapan basis akrual adalah adanya Laporan Operasional (LO) yang menjadi wadah pelaporan pendapatan akrual. Dalam LO, pendapatan akan diklasifikasikan menurut sumber 
pendapatan, yaitu pendapatan perpajakan, pendapatan bukan pajak dan pendapatan hibah. Sesuai dengan penelitian ini maka yang dibahas adalah pengakuan pendapatan perpajakannya saja. Berdasarkan PP 71 Tahun 2010, pendapatan LO diakui pada saat:

1. Timbulnya hak atas pendapatan;

2. Pendapatan direalisasi, yaitu adanya aliran masuk sumber daya ekonomi;

Hal ini berarti berdasarkan basis akrual untuk LO pendapatan diakui pada saat hak untuk memperoleh pendapatan telah terpenuhi walaupun kas (aliran masuk sumber daya ekonomi) belum diterima di Rekening Kas Umum Negara atau oleh entitas pelaporan.

Dalam PP 71 tahun 2010 tidak terdapat penjelasan lebih lanjut mengenai saat timbulnya hak pemerintah terkait pendapatan perpajakan. Saat timbulnya hak pemerintah terhadap perpajakan harus diperjelas mengingat sistem perpajakan Indonesia menganut self assessment, dimana wajib pajak diberikan amanah untuk menghitung sendiri kewajiban perpajakannya.

Hal ini dapat menjadi kendala jika dikaitkan dengan konsep kemungkinan besar manfaat ekonomi masa depan terjadi, yaitu dalam pengakuan pendapatan harus terdapat kepastian tinggi bahwa manfaat ekonomi masa depan yang berkaitan dengan pos pendapatan akan mengalir ke entitas pelaporan. Derajat kepastian yang melekat pada arus manfaat ekonomi di masa datang harus dilakukan atas dasar bukti yang dapat diperoleh pada saat penyusunan laporan keuangan. Untuk lebih jelasnya, penulis merujuk pada penjelasan Bambang Widjajarso dalam tulisan Penerapan Basis Akrual Pada Akuntansi Pemerintah Indonesia. Jika basis akrual diterapkan, pendapatan diakui pada saat timbul hak dari pemerintah. Masalahnya adalah dalam hak pajak yang menganut self assessment dimana wajib pajak menghitung sendiri kewajiban pajaknya, hak tersebut menjadi belum final - karena masih dimungkinkan adanya restitusi meskipun sudah ada SPT, sehingga dokumen yang dijadikan dasar penentuan hak tagih pajak menjadi masalah.

Penulis (Bambang Widjajarso) merasa perlu menambah bahasan pengakuan pendapatan dan belanja/beban untuk memperluas wawasan dari bahasan sebelumnya. Memang benar, pendapatan harus diakui jika telah muncul hak sehingga pencatatan pendapatan dilakukan setiap kali ada transaksi munculnya hak tersebut. Logikanya, standar akuntansi pemerintah nantinya harus menciptakan kriteria yang jelas atas pengakuan pendapatan tersebut. Misalnya, seperti yang diterapkan oleh State and Local Governments di Amerika, pendapatan diakui jika terpenuhinya kriteria. measurable dan available. Dengan demikian, pendapatan pajak yang harus diakui adalah jika dapat diukur dan tersedia untuk operasi entitas pelaporan. Contoh jenis pajak yang memenuhi kriteria seperti itu adalah pajak property, misalnya $\mathrm{Pa}$ jak Bumi Bangunan, Pajak Kendaraan Bermotor dan sebagainya. Dalam kondisi itu, pajak property harus langsung diakui dan dicatat sebagai pendapatan. Bagaimana dengan pajak yang lain?

Untuk jenis pajak yang lain, misalnya Pajak Penghasilan, menurut penulis (Bambang Widjajarso), kriteria dapat diukur dan tersedia tetap harus diberlakukan. Jika kedua kriteria tersebut tidak secara bersamaan dapat terpenuhi, pendapatan pajak jenis itu tidak dapat diakui sebagai pendapatan. Alternatifnya, karena pendapatan pajak mempunyai karakteristik non exchange revenues, peraturan perpajakan harus ditafsirkan oleh badan penyusun standar akuntansi pemerintahan kapan memenuhi kriteria measurable dan kapan memenuhi available. Suatu angsuran pajak, misalnya, yang belum secara definitif dapat dikatakan sebagai hak negara, tidak dapat diakui sebagai pendapatan pajak, kecuali pada jenis usaha tertentu, misalnya pada perbankan yang diwajibkan menyusun laporan keuangan triwulanan dan sekaligus menyampaikan kewajiban pajaknya melalui SPT Masa, dapat diakui sebagai pendapatan pajak oleh pemerintah. Jika SPT mempunyai dasar keterukuran pendapatan pajak dan jika batas restitusi bisa ditentukan, pajak penghasilan baru dapat diakui sebagai pendapatan.

Untuk jenis pajak yang lain, misalnya Pajak Pertambahan Nilai, menurut penulis (Bambang Widjajarso), kriteria diatas juga tetap berlaku. Artinya, penyampaian SPT Masa dalam pajak jenis itu dapat dijadikan dasar pengakuan pendapatan PPN, karena pada saat SPT Masa telah dis- 
ampaikan, kedua kriteria pendapatan telah terpenuhi, sehingga pendapatan yang berasal dari PPN dapat diakui. Untuk pajak lainnya, seyogyanya diberlakukan analogi bahasan pemenuhan kriteria seperti pada Pajak Penghasilan dan Pajak Pertambahan Nilai. Dari pendapat Bambang Widjajarso dapat disimpulkan bahwa pendapatan perpajakan dapat diakui secara akrual bila telah memenuhi kriteria measurable dan available. Pemerintah akan mengakui adanya pendapatan perpajakan yang timbul dari hak atas pendapatan tersebut, walaupun aliran masuk sumber daya ekonomi belum terjadi. Selain itu harus terdapat dasar atau bukti untuk meyakinkan adanya kepastian tinggi manfaat ekonomi di masa depan akan terealisasi dan mengalir ke entitas pelaporan. Salah satu dokumen yang menunjukkan bahwa pendapatan memenuhi kriteria tersebut adalah SPT yang disampaikan wajib pajak.

Basis yang digunakan untuk pendapatan perpajakan di KPP Pratama Baubau tahun 2014 adalah basis akrual penuh, yaitu basis yang mengakui pendapatan, beban, aset, utang dan ekuitas dalam pelaporan finansial berbasis akrual, serta mengakui pendapatan, belanja, dan pembiayaan dalam pelaporan pelaksanaan anggaran berdasarkan basis yang ditetapkan dalam APBN. Sesuai dengan PP 71 Tahun 2010 lampiran I menyatakan bahwa Pendapatan LO diakui pada saat timbulnya hak atas pendapatan tersebut atau ada aliran masuk sumber daya ekonomi. Dan Pendapatan LRA diakui pada saat kas diterima di Rekening Kas Umum Negara atau oleh entitas pelaporan. Dalam hal pengakuan pendapatan, KPP Pratama Baubau telah melaksanakan aturan sesuai dengan PP 71 Tahun 2010.

\section{KESIMPULAN}

Berdasarkan penelitian yang dilakukan pada KPP Pratama Baubau mengenai analisis akuntansi pendapatan perpajakan dalam rangka penerapan akuntansi berbasis akrual, maka penulis mengambil kesimpulan sebagai berikut:
1. Akuntansi berbasis akrual akan meningkatkan kualitas pelaporan keuangan pemerintah karena menghasilkan informasi yang lebih akuntabel, andal, dan transparan dibandingkan dengan akuntansi berbasis kas. Dengan penggunaan basis akrual pada lingkungan pemerintah, maka akan tersedia pengukuran yang lebih baik, pengakuan yang tepat waktu, dan pengungkapan kewajiban di masa mendatang. Informasi berbasis akrual dapat menyediakan informasi mengenai penggunaan sumber daya ekonomi yang sebenarnya.

2. Dalam akuntansi pendapatan berbasis akrual, terdapat dua jenis pendapatan, yaitu Pendapatan LRA (Laporan Realisasi Anggaran) dan Pendapatan LO (Laporan Operasional). Pendapatan LRA merupakan pendapatan yang digunakan untuk kepentingan penganggaran yang masih memakai basis kas. Sedangkan Pendapatan LO merupakan pendapatan yang diakui dengan basis akrual.

3. Pendapatan perpajakan merupakan sumber penerimaan terbesar dalam APBN Indonesia. Oleh karena itu penyajian pendapatan perpajakan dalam Laporan Keuangan Pemerintah memiliki materialitas tinggi dan harus mendapatkan perhatian lebih.

4. KPP Pratama Baubau telah melaksanakan akuntansi pendapatan perpajakan dengan basis akrual berdasarkan aturan yang berlaku, yaitu PP 71 tahun 2010 dan aturan pendukung lainnya. Pendapatan perpajakan diakui ketika munculnya hak pemerintah atas pendapatan perpajakan. Pencatatan pendapatan perpajakan telah dilaksanakan sesuai dengan jurnal standar Standar Akuntansi Instansi. Pelaporan Pendapatan Perpajakan KPP Pratama Baubau disajikan dalam Laporan Realisasi Anggaran dan Laporan Operasional. 


\section{REFERENSI}

Amir, A.Tri Abdiawan.dkk. 2012, "International Accounting Issues and Practices-Accrual Based Accounting” bramastia.candra@gmail.com (29 September 2012)

Bastian, Indra. 2006. Akuntansi Sektor Publik: Suatu Pengantar. Jakarta:Erlangga.

Brotodihardjo, R Santoso, 2003. Pengantar Ilmu Hukum Pajak, Edisi ke Empat, Refika Aditama, Bandung.

Daholi Hadi T.Qivi, 2013 Analisis Akuntansi Pendapatan Perpajakan Dalam Rangka Penerapan Akuntansi Berbasis Akrual (Studi Kasus : KPP Pratama Medan Kota), Universitas Sumatra Utara.

Departemen Keuangan RI, 2009. Modul Sistem Akuntansi Pemerintah Pusat, Program Percepatan Akuntabilitas Keuangan Pemerintah (PPAKP), Jakarta.

Departemen Keuangan RI, 2009. Modul Standar Akuntansi Pemerintahan, Program Percepatan Akuntabilitas Keuangan Pemerintah (PPAKP), Jakarta.

Direktorat Jenderal Pajak, 2011. Laporan Keuangan Direktorat Jenderal Pajak TA-2011 Audited, Direktorat Jenderal Pajak, Jakarta (diakses dari www.pajak.go.id)

Halim, Abdul, 2008. Akuntansi Sektor Publik; Akuntansi Keuangan Daerah, Edisi 3, Salemba Empat, Jakarta.

International Public Sector Accounting Standards Board, 2011. Transition to the Accrual Basisof Accounting: Guidance for Public Sector Entities-Third Edition, International Federation of Accountants, New York. (diakses dari www.ifac.org)

International Public Sector Accounting Standards Board, 2006. International Public Sector Accounting Standard (IPSAS) No 23-Revenue From Non Exchange Transactions (Taxes and Transfers), International Federationof Accountants, NewYork.(diakses dari www.ifac.org)

Komite Standar Akuntansi Pemerintahan, 2006. Memorandum Pembahasan Penerapan Basis Akrual Dalam Akuntansi Pemerintahan di Indonesia-Bahan Bahasan Untuk Limited Hearing, KSAP, Jakarta. (diakses dari www. ksap.org)

Kurniawan, Validita, 2012. “Analisis Akuntansi Pendapatan Pajak Penghasilan Pasal 25 Dalam Rangka Implementasi Basis Akrual Studi Kasus: Kantor Pelayanan Pajak Pratama Semarang Tengah Dua”, amin_awf@yahoo.co.id (diakses 25 Juni 2015)

Manihuruk, Wiston, 2011. "Penetapandan Ketetapan Pajak", http://wistonmanihuruk.blogspot. com/2011/04/penetapan-dan-ketetapan-pajak.html (diakses25 Juni 2015)

Mardiasmo, 2009. Akuntansi Sektor Publik, Edisi IV, Penerbit Andi, Yogyakarta.

Pemerintah Republik Indonesia, 1983. Undang-Undang Nomor No.6 Tahun 1983 dan Undang-Undang Nomor 16 Tahun 2009 tentang Ketentuan Umum dan Tata Cara Perpajakan, Jakarta. 
Prastowo, Yustinus, 2010. Panduan Lengkap Pajak, Raih Asa Sukses, Jakarta. Pratiwi, Ayu dhia Indah. dkk. 2012, “Transisi Penerapan Akuntansi Pemerintah Berbasis Akrual”, bramastia.candra@ gmail.com (25 Juni 2015)

Rakhman, Azwar. dkk. 2012,"Penyajian LKPP berdasarkan SAP Berbasis Akrual”, bramastia. candra@gmail.com (25 Juni 2015)

Rusmana, Oman dan Esti Saraswati, "Conversion Of Local Government Financial Report (LKPD) Cash Toward Accrual Basis To Become Acrual Basis (Case Study in Local Government of Cirebon City)", http://www.journal.unipdu.ac.id/index.php/seminas/article/download/37/37(diakses23 Juni 2015)

Soemitro, Rochmat dan Dewi Kania Sugiharti, 2004. Asas dan Dasar Perpajakan, Edisi kedua (revisi), Refika Aditama, Bandung. 
RUDI ABDULLAH 